\title{
New Terpenoids from the Soft Corals Sinularia capillosa and Nephthea chabroli
}

2009

Vol. 11, No. 21

$4830-4833$

\section{Shi-Yie Cheng, ${ }^{\dagger, \| l}$ Ki-Jhih Huang, ${ }^{\dagger}$ Shang-Kwei Wang, ${ }^{\ddagger}$ Zhi-Horng Wen, ${ }^{\dagger}$ Chi-Hsin Hsu, ${ }^{\dagger}$ Chang-Feng Dai, ${ }^{\S}$ and Chang-Yih Duh ${ }^{\star,},, \| l$}

Department of Marine Biotechnology and Resources, National Sun Yat-Sen University,

Kaohsiung, Taiwan, Department of Microbiology, Kaohsiung Medical University,

Kaohsiung, Taiwan, Institute of Oceanography, National Taiwan University, Taipei,

Taiwan, and Asia-Pacific Ocean Research Center, National Sun Yat-sen University,

Kaohsiung, Taiwan

yihduh@mail.nsysu.edu.tw

Received August 11, 2009

\section{ABSTRACT}

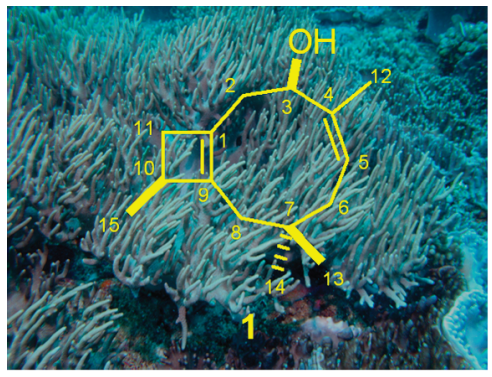

Sinularia capillosa

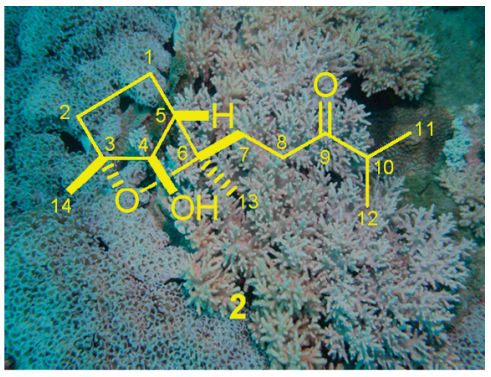

Nephthea chabroli

Two new terpenoids, capillosanol (1) and chabranol (2), possessing unprecedented terpenoid skeletons, were isolated from the soft corals Sinularia capillosa and Nephthea chabroli, respectively. The structures of 1 and 2 were elucidated through extensive spectroscopic analyses. The cytotoxicities of these compounds were tested in vitro.

Soft corals, especially those of the genera Sinularia and Nephthea, have been well recognized as a rich source of sesquiterpenoids, providing a wide range of structural diversity ${ }^{1-12}$ and exhibiting various bioactivities such as

\footnotetext{
National Sun Yat-Sen University.

Kaohsiung Medical University.

$\S$ National Taiwan University.

"Asia-Pacific Ocean Research Center.

(1) Blunt, J. W.; Copp, B. R.; Hu, W.-P.; Munro, M. H. G.; Northcote,

P. T.; Prinsep, M. R. Nat. Prod. Rep. 2009, 26, 170.

(2) Kamel, H. N.; Slattery, M. Pharm. Biol. 2005, 43, 253.

(3) Ahmed, A. F.; Kuo, Y.-H.; Dai, C.-F.; Sheu, J.-H. J. Nat. Prod. $\mathbf{2 0 0 5}, 68,1208$.

(4) Chao, C.-H.; Hsieh, C.-H.; Chen, S.-P.; Lu, C.-K.; Dai, C.-F.; Wu, Y.-C.; Sheu, J.-H. Tetrahedron Lett. 2006, 47, 2175.

(5) Chao, C.-H.; Hsieh, C.-H.; Chen, S.-P.; Lu, C.-K.; Dai, C.-F.; Sheu, J.-H. Tetrahedron Lett. 2006, 47, 5889.
}

(6) Cheng, S.-Y.; Dai, C.-F.; Duh, C.-Y. J. Nat. Prod. 2007, 70, 1449. cytotoxic, ${ }^{3,6-9}$ anti-inflammatory, ${ }^{9,10}$ and antimicrobial properties. $^{2,10}$

As part of a continuing search for bioactive substances from marine invertebrates, we explored the chemical investigations of the Formosan soft corals $S$. capillosa Tixier-

(7) El-Gamal, A. A. H.; Wang, S.-K.; Dai, C.-F.; Duh, C.-Y. J. Nat. Prod. 2004, 67, 1455 .

(8) Wang, S.-K.; Duh, C.-Y. Chem. Pharm. Bull. 2007, 55, 762.

(9) Cheng, S.-Y.; Wen, Z.-H.; Wang, S.-K.; Chiang, M. Y.; El-Gamal, A. A. H.; Dai, C.-F.; Duh, C.-Y. Chem. Biodiversity 2009, 6, 86.

(10) Cheng, S.-Y.; Huang, Y.-C.; Wen, Z.-H.; Chiou, S.-F.; Wang, S.K.; Hsu, C.-H.; Dai, C.-F.; Duh, C.-Y. Tetrahedron Lett. 2009, 50, 802.

(11) Anjaneyulu, A. S. R.; Gowri, P. M.; Krishna Murthy, M. V. R. J. Nat. Prod. 1999, 62, 1600.

(12) Bowden, B. F.; Coll, J. C.; Mitchell, S. J. Aust. J. Chem. 1980, 33, 1833 
Durivault and N. chabroli Audouin, which were collected from the Dongsha Atoll and Siaoliouciou Island, respectively.

Chromatographic separation on the acetone extracts of the soft corals $S$. capillosa and $N$. chabroli resulted in the isolation of two new terpenoids, named as capillosanol (1) and chabranol (2), respectively (Figure 1).

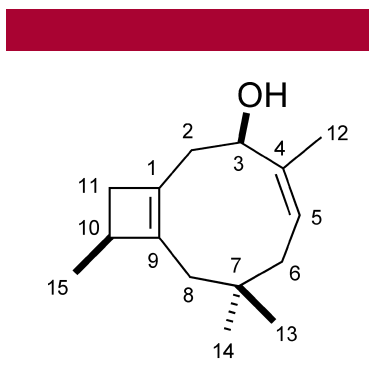

1

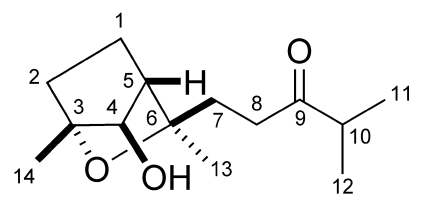

2

Figure 1. Structures of metabolites $\mathbf{1}$ and 2.

The acetone extract of $S$. capillosa was concentrated to a brown gum, which was partitioned between EtOAc and $\mathrm{H}_{2} \mathrm{O}$. The EtOAc-soluble residue (60 g) was subjected to $\mathrm{CC}$ on silica gel using $n$-hexane-EtOAc mixtures of increasing polarity to yield 40 fractions. Fraction $14(0.8 \mathrm{~g})$ was applied to a $\mathrm{C}_{18}$ gel column to obtain a mixture $(72 \mathrm{mg})$ that was further purified by HPLC (LiChrosorb RP-18, $7 \mu \mathrm{m}, 25 \times$ $250 \mathrm{~mm})$, eluting with $\mathrm{MeOH}-\mathrm{H}_{2} \mathrm{O}(85: 15)$ to yield $\mathbf{1}(2.0$ $\mathrm{mg})$. In the same manner, the EtOAc fraction (100 g) of the other soft coral $N$. chabroli was subjected to CC on silica gel to furnish 40 fractions. Fraction 16 (1.5 g) was fractionated over Sephadex LH-20 eluting with $\mathrm{MeOH}$ followed by RP-18 HPLC purification using $\mathrm{MeOH}-\mathrm{H}_{2} \mathrm{O}(75: 25)$ as eluent to give 2 (1.0 $\mathrm{mg})$.

Capillosanol (1) ${ }^{13}$ was obtained as a white amorphous powder. The positive HRESIMS of $\mathbf{1}$ exhibited a pseudomolecular ion peak at $\mathrm{m} / \mathrm{z} 243.1727[\mathrm{M}+\mathrm{Na}]^{+}$, consistent with the molecular formula of $\mathrm{C}_{15} \mathrm{H}_{24} \mathrm{O}$, implying four degrees of unsaturation. Its IR spectrum absorptions at 3426 $\mathrm{cm}^{-1}$ indicated the presence of a secondary hydroxyl, which was supported by the ${ }^{1} \mathrm{H}$ and ${ }^{13} \mathrm{C}$ NMR signals (Table 1) resonating at $\delta_{\mathrm{H}} 4.77(1 \mathrm{H}, \mathrm{br} \mathrm{s}, \mathrm{H}-3)$ and $\delta_{\mathrm{C}} 71.0(\mathrm{CH}, \mathrm{C}-3)$. Meanwhile, the HMBC correlations (Figure 2) observed from $\mathrm{H}_{3}-12$ to C-3, C-4, and C-5 led to the position of the hydroxyl at $\mathrm{C}-3$. The NMR spectra of $\mathbf{1}$ contained resonances for a trisubstituted double bond $\left[\delta_{\mathrm{H}} 5.59(\mathrm{br} \mathrm{s}, 1 \mathrm{H}) ; \delta_{\mathrm{C}} 139.5(\mathrm{qC})\right.$ and $122.3(\mathrm{CH})]$ and a tetrasubstituted double bond $\left[\delta_{\mathrm{C}} 130.2\right.$ (qC) and $142.5(\mathrm{qC})]$. The above moieties accounted for two of the four degrees of unsaturation, indicating a bicyclic structure for metabolite $\mathbf{1}$.

From the COSY spectrum (Figure 2) of 1, it was possible to establish the proton connects from $\mathrm{H}-3$ to $\mathrm{H}_{3}-15$ through $\mathrm{H}_{2}-2, \mathrm{H}_{2}-11$, and $\mathrm{H}-10$, and from $\mathrm{H}_{2}-6$ to $\mathrm{H}_{3}-12$ through $\mathrm{H}-5$, as well as a long-range COSY correlation between $\mathrm{H}_{2}-2$ and

(13) Capillosaniol (1): white amorphous powder; $[\alpha]^{25}+114$ (c 0.1 , $\mathrm{CHCl}_{3}$ ); IR (KBr) v $\mathrm{v}_{\max } 3426,2928,1655,1449,1373 \mathrm{~cm}^{-1} ;{ }^{1} \mathrm{H}$ NMR and ${ }^{13} \mathrm{C}$ NMR data, see Table 1; ESIMS $\mathrm{m} / \mathrm{z} 243[\mathrm{M}+\mathrm{Na}]^{+}$; HRESIMS $\mathrm{m} / \mathrm{z}$ $243.1727[\mathrm{M}+\mathrm{Na}]^{+}$(calcd for $\mathrm{C}_{15} \mathrm{H}_{24} \mathrm{ONa}, 243.1725$ ).
Table 1. ${ }^{1} \mathrm{H}$ and ${ }^{13} \mathrm{C}$ NMR Spectroscopic Data of $\mathbf{1}^{a}$

\begin{tabular}{lcl}
\hline & \multicolumn{1}{c}{1} \\
\cline { 2 - 3 } $\mathrm{C} / \mathrm{H}$ & ${ }^{13} \mathrm{C}$ & \multicolumn{1}{c}{${ }^{1} \mathrm{H}$} \\
\hline 1 & $130.2(\mathrm{qC})^{b}$ & \\
2 & $34.5\left(\mathrm{CH}_{2}\right)$ & $\mathrm{a}: 1.76 \mathrm{~m} ; \mathrm{b}: 1.54 \mathrm{~m}$ \\
3 & $71.0(\mathrm{CH})$ & $4.77 \mathrm{br} \mathrm{s}$ \\
4 & $139.5(\mathrm{qC})$ & \\
5 & $122.3(\mathrm{CH})$ & $5.59 \mathrm{br} \mathrm{s}$ \\
6 & $53.1(\mathrm{CH})$ & $\mathrm{a}: 2.31 \mathrm{~d}(15.5) ;{ }^{c} \mathrm{~b}: 2.02 \mathrm{~d}(15.5)$ \\
7 & $37.2(\mathrm{qC})$ & \\
8 & $54.0(\mathrm{CH})$ & $\mathrm{a}: 2.20 \mathrm{~d}(15.0) ; \mathrm{b}: 1.92 \mathrm{~d}(15.0)$ \\
9 & $142.5(\mathrm{qC})$ & \\
10 & $37.9\left(\mathrm{CH}^{1}\right)$ & $2.25 \mathrm{~m}$ \\
11 & $32.1\left(\mathrm{CH}_{2}\right)$ & $\alpha: 1.82 \mathrm{~d}(13.0) ; \beta: 1.40 \mathrm{~d}(13.0)$ \\
12 & $17.7\left(\mathrm{CH}_{3}\right)$ & $1.68 \mathrm{~s}$ \\
13 & $29.5\left(\mathrm{CH}_{3}\right)$ & $1.02 \mathrm{~s}$ \\
14 & $29.6\left(\mathrm{CH}_{3}\right)$ & $1.03 \mathrm{~s}$ \\
15 & $23.1\left(\mathrm{CH}_{3}\right)$ & $0.97 \mathrm{~d}(7.0)$ \\
$3-\mathrm{OH}$ & & $3.78 \mathrm{~d}(4.0)$
\end{tabular}

${ }^{a}$ Spectra were measured in $\mathrm{CD}_{3} \mathrm{COCD}_{3}\left({ }^{1} \mathrm{H}, 500 \mathrm{MHz}\right.$ and ${ }^{13} \mathrm{C}, 125$ MHz). ${ }^{b}$ Multiplicities are deduced by HSQC and DEPT experiments. ${ }^{c} J$ values (in $\mathrm{Hz}$ ) are in parentheses.

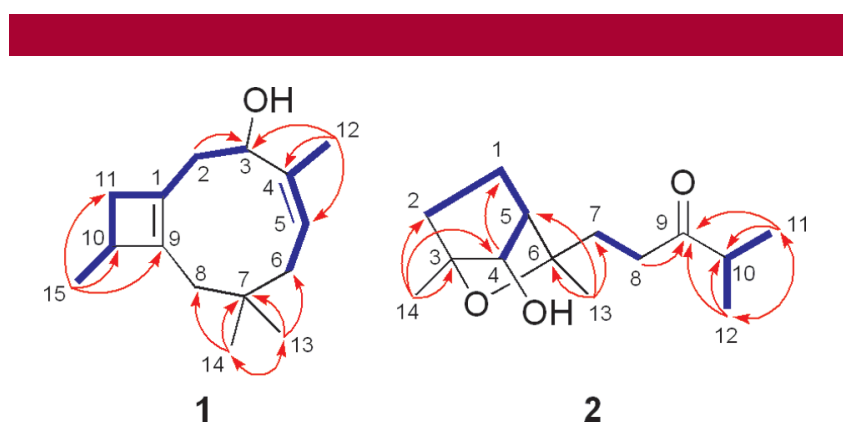

Figure 2. Selected ${ }^{1} \mathrm{H}-{ }^{1} \mathrm{H} \operatorname{COSY}(-)$ and key $\mathrm{HMBC}(\rightarrow)$ correlations of $\mathbf{1}$ and $\mathbf{2}$.

$\mathrm{H}_{2}-11 ; \mathrm{H}-5$ and $\mathrm{H}_{3}-12$ (Figure 2). The connectivities between C-9 and C-10; C-3 and C-4 were elucidated on the basis of the HMBC correlations from $\mathrm{H}_{3}-15$ to $\mathrm{C}-9, \mathrm{C}-10$, and $\mathrm{C}-11$ and from $\mathrm{H}_{3}-12$ to $\mathrm{C}-3, \mathrm{C}-4$, and C-5. Moreover, the HMBC spectrum showed correlations from $\mathrm{H}_{3}-13 / \mathrm{H}_{3}-14$ to $\mathrm{C}-6, \mathrm{C}-7$, and $\mathrm{C}-8$, proving the attachment between $\mathrm{C}-6$ and $\mathrm{C}-8$ through $\mathrm{C}-7$. Although there were no direct HMBC correlations available, the remaining one unsaturation indicated that C-8 should be linked to C-9. This assumption was further supported by the NOESY correlation from $\mathrm{H}-8 \mathrm{a}\left(\delta_{\mathrm{H}} 2.21\right)$ to $\mathrm{H}_{3}-15$ (Figure 3 ). The long-range COSY correlation between $\mathrm{H}_{2}-2$ and $\mathrm{H}_{2}-11$ is attributed to the W-type coupling $\left({ }^{4} J_{2,11}\right)$ of the highly strained ring system, which was further identified by the crucial NOESY correlation between $\mathrm{H}-11 \beta$ and $\mathrm{H}-2 \mathrm{a}$ and absence of the NOESY correlations between $\mathrm{H}_{2}-2$ and Me-15. Accordingly, the planar structure of metabolite 1, possessing a bicyclo[7.2.0] undecane moiety, was proposed decidedly.

The geometry of the trisubstituted olefin was assigned as $Z$ based on the NOESY correlations (Figure 3) between H-5 and $\mathrm{H}_{3}-12$. The crucial NOE correlations between $\mathrm{H}-10$ with 

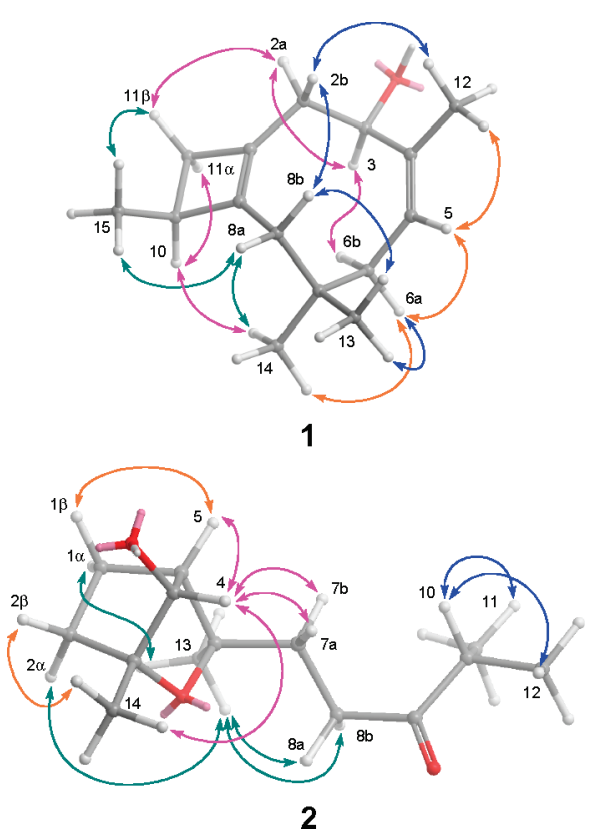

Figure 3. Key NOE correlations of $\mathbf{1}$ and 2.

$\mathrm{H}-11 \alpha\left(\delta_{\mathrm{H}} 1.83\right)$ suggested that the two protons were oriented on the same side of the cyclobutene moiety, while $\mathrm{H}_{3}-15$ was oriented on the opposite side. Moreover, $\mathrm{H}-2 \mathrm{~b}\left(\delta_{\mathrm{H}} 1.54\right)$ was found to show NOE correlations with $\mathrm{H}-8 \mathrm{~b}\left(\delta_{\mathrm{H}} 1.93\right)$ and $\mathrm{H}_{3}-12$, and $\mathrm{H}-3$ exhibited NOE correlations with $\mathrm{H}-6 \mathrm{~b}$ $\left(\delta_{\mathrm{H}} 2.00\right)$ and $\mathrm{H}-2 \mathrm{a}\left(\delta_{\mathrm{H}} 1.76\right)$, indicating the $\beta$-orientation of $3-\mathrm{OH}$. The above findings indicated the $3 R^{*}$ and $10 S^{*}$ configurations as depicted in Figure 3. The results, together with other detailed NOESY correlations (Figure 3) of 1, determined the structure of capillosanol as shown in the formula 1.

Chabranol (2) ${ }^{14}$ was isolated as a colorless, viscous oil. HRESIMS of metabolite $\mathbf{2}$ exhibited a pseudomolecular ion peak at $m / z 263.1625[\mathrm{M}+\mathrm{Na}]^{+}$and established a molecular formula of $\mathrm{C}_{14} \mathrm{H}_{24} \mathrm{O}_{3}$, indicating three degrees of unsaturation. The ${ }^{13} \mathrm{C}$ NMR (Table 1) displayed 14 carbon signals, which were identified by the assistance of the DEPT spectrum as four methyls, four methylenes, three methines, and three quaternary carbons. The ${ }^{1} \mathrm{H}$ NMR signal $\left[\delta_{\mathrm{H}} 4.13(\mathrm{br} \mathrm{s}, 1 \mathrm{H})\right]$ (Table 2) and a broad IR absorption at $3437 \mathrm{~cm}^{-1}$, together with the observation of one oxygen-bearing carbon resonance $\left(\delta_{\mathrm{C}} 79.3\right)$ in ${ }^{13} \mathrm{C}$ NMR spectrum, revealed the presence of one hydroxyl. Furthermore, a keto-carbonyl carbon was recognized as being present in $\mathbf{2}$ from its ${ }^{13} \mathrm{C}$ NMR signal at $\delta_{\mathrm{C}} 212.2$ (qC, C-9), as well as from a strong IR absorption at $1714 \mathrm{~cm}^{-1}$. By interpretation of COSY correlations (Figure 2 ), it was possible to establish three partial structures from $\mathrm{H}_{2}-2$ to $\mathrm{H}-4$ through $\mathrm{H}_{2}-1$ and $\mathrm{H}-5$ and from $\mathrm{H}_{3}-11$ to $\mathrm{H}_{3}-12$ through $\mathrm{H}-10$, as well as COSY correlation between $\mathrm{H}_{2}-7$ and $\mathrm{H}_{2}-8$. The connectivities of these partial structures were

(14) Chabranol (2): colorless, viscous oil; $[\alpha]^{25}-56$ (c $\left.0.1, \mathrm{CHCl}_{3}\right)$; IR (KBr) $v_{\max } 3437,2969,2937,1714,1458,1374 \mathrm{~cm}^{-1}$; ${ }^{1} \mathrm{H}$ NMR and ${ }^{13} \mathrm{C}$ NMR data, see Table 1; ESIMS $\mathrm{m} / \mathrm{z} 263[\mathrm{M}+\mathrm{Na}]^{+}$; HRESIMS $\mathrm{m} / \mathrm{z}$ $263.1625[\mathrm{M}+\mathrm{Na}]^{+}$(calcd for $\mathrm{C}_{14} \mathrm{H}_{24} \mathrm{O}_{3} \mathrm{Na}, 263.1623$ ).
Table 2. ${ }^{1} \mathrm{H}$ and ${ }^{13} \mathrm{C}$ NMR Spectroscopic Data of $\mathbf{2}^{a}$

\begin{tabular}{rll}
\hline & \multicolumn{2}{c}{2} \\
\cline { 2 - 3 } $\mathrm{C} / \mathrm{H}$ & \multicolumn{1}{c}{${ }^{13} \mathrm{C}$} & \multicolumn{1}{c}{${ }^{1} \mathrm{H}$} \\
\hline 1 & $22.5\left(\mathrm{CH}_{2}\right)^{b}$ & $\alpha: 1.84 \mathrm{~m} ; \beta: 2.64 \mathrm{~m}$ \\
2 & $33.0\left(\mathrm{CH}_{2}\right)$ & $\alpha: 1.44 \mathrm{~m} ; \beta: 1.62 \mathrm{~m}$ \\
3 & $84.5(\mathrm{qC})$ & \\
4 & $79.3(\mathrm{CH})$ & $4.13 \mathrm{br} \mathrm{s}$ \\
5 & $50.2(\mathrm{CH})$ & $2.00 \mathrm{br} \mathrm{s}$ \\
6 & $78.7(\mathrm{qC})$ & \\
7 & $36.0\left(\mathrm{CH}_{2}\right)$ & a: $1.91 \mathrm{~m} ; \mathrm{b}: 1.57 \mathrm{~m}$ \\
8 & $35.4\left(\mathrm{CH}_{2}\right)$ & a: $2.63 \mathrm{~m} ; \mathrm{b}: 2.35 \mathrm{~m}$ \\
9 & $212.2(\mathrm{qC})$ & \\
10 & $41.7\left(\mathrm{CH}^{2}\right)$ & $2.58 \mathrm{~m}$ \\
11 & $19.5\left(\mathrm{CH}_{3}\right)$ & $1.09 \mathrm{~d}(7.2)^{c}$ \\
12 & $19.3\left(\mathrm{CH}_{3}\right)$ & $1.11 \mathrm{~d}(7.2)$ \\
13 & $24.0\left(\mathrm{CH}_{3}\right)$ & $1.16 \mathrm{~s}$ \\
14 & $18.1\left(\mathrm{CH}_{3}\right)$ & $1.20 \mathrm{~s}$
\end{tabular}

${ }^{a}$ Spectra were measured in $\mathrm{CDCl}_{3}\left({ }^{1} \mathrm{H}, 400 \mathrm{MHz}\right.$ and $\left.{ }^{13} \mathrm{C}, 100 \mathrm{MHz}\right)$. ${ }^{b}$ Multiplicities are deduced by HSQC and DEPT experiments. ${ }^{c} J$ values (in $\mathrm{Hz}$ ) are in parentheses.

further established by the HMBC correlations (Figure 2). Moreover, the HMBC correlations observed from $\mathrm{H}_{2}-8 / \mathrm{H}_{3}$ $11 / \mathrm{H}_{3}-12$ to $\mathrm{C}-9$ indicated the position of the keto-carbonyl group at C-9. To confirm the position of the ether linkage, 2 was submitted to acetylation with $\mathrm{Ac}_{2} \mathrm{O}$ in pyridine at room temperature overnight. Formation of monoacetylated derivative $2 \mathbf{a}^{15}$ proved the presence of a secondary hydroxyl in the original structure. The HMBC correlations observed from $\mathrm{H}_{3}-14$ to $\mathrm{C}-2 / \mathrm{C}-3 / \mathrm{C}-4$ led to the assignment of the hydroxyl at $\mathrm{C}-4$. Indeed, the position of the ether linkage at C-3/C-6 was confirmed by the above observations. Thus, the gross structure of $\mathbf{2}$, possessing a cyclopentane ring fused to a tetradrofuran ring at C-3 and C-6, was elucidated unmistakably.

The relative configuration of $\mathbf{2}$ was determined through inspection of the NOESY spectrum as well as a computergenerated lower energy conformation using MM2 force field calculations (Figure 3). From the NOESY spectrum of 2, $\mathrm{H}-1 \beta$ was found to show an NOE correlation with $\mathrm{H}-5$, and $\mathrm{H}-2 \beta$ exhibited an NOE correlation with $\mathrm{H}_{3}-14$, indicating the $\beta$-orientations of $\mathrm{H}-5$ and $\mathrm{H}_{3}-14$. In addition, $\mathrm{H}-4$ was determined as $\alpha$ on the basis of the analysis of coupling constants and splitting patterns of H-5. This finding was supported by the observation of a very small coupling constant (close to zero) between $\mathrm{H}-4$ and $\mathrm{H}-5$, implying the dihedral angle between the above two protons was almost $90^{\circ}$, consistent with the observation in the computer-modeled structure of $\mathbf{2}$. Furthermore, the NOE correlations could be observed between $\mathrm{H}-1 \alpha / \mathrm{H}_{3}-13$ and $\mathrm{H}-2 \alpha / \mathrm{H}_{3}-13$. Thus, $\mathrm{H}_{3}-$ 13 should be placed on the $\alpha$ face. The above findings indicated the $3 R^{*}, 4 R^{*}, 5 S^{*}, 6 R^{*}$ configuration as depicted in

(15) 4(R*)-Acetoxychabranol (2a): colorless, viscous oil; $[\alpha]^{25}-38$ (c $\left.0.1, \mathrm{CHCl}_{3}\right)$; selected ${ }^{1} \mathrm{H} \mathrm{NMR}\left(\mathrm{CDCl}_{3}, 400 \mathrm{MHz}\right) \delta 4.92(1 \mathrm{H}$, br s, H-4), $2.63(1 \mathrm{H}, \mathrm{m}, \mathrm{H}-8 \mathrm{a}), 2.39$ (1H, m, H-8b), 2.60 (1H, m, H-10), 2.44 $(1 \mathrm{H}, \mathrm{m}, \mathrm{H}-1 \beta), 2.28(1 \mathrm{H}, \mathrm{br} \mathrm{s}, \mathrm{H}-5), 2.08(3 \mathrm{H}, \mathrm{s}, 4-\mathrm{OAc}), 1.21(3 \mathrm{H}, \mathrm{s}$, Me-14), 1.17 (3H, s, Me-13), 1.11 (3H, d, $J=6.8, \mathrm{Me}-12), 1.10(3 \mathrm{H}, J=$ 6.8, Me-11); ESIMS m/z $305.4[\mathrm{M}+\mathrm{Na}]^{+}$. 
Figure 3. On the basis of the above observations and other detailed NOESY correlations (Figure 3), the structure of chabranol (2) was established unambiguously.

It is worthwhile to mention that metabolite $\mathbf{1}$ has a previously unknown carbon skeleton. We propose the name "capillosane" for this new skeleton. Farnesyl pyrophosphate may be involved in the biosynthesis of compound $\mathbf{1}$ through cyclization, oxidation, 1,3-hydrogen shift, 1,2-methyl migration, 1,2-hydrogen shift, and deprotonation to result in the formation of a capillosane-type skeleton (see the Supporting Information). A possible biosynthetic pathway for the loss of a carbon fragment from cyclopentane sesquiterpene by enzymatic oxidative modifications that could provide a cyclopentane norsesquiterpene skeleton of $\mathbf{2}$ was postulated.

Compounds 1, 2, and 2a were evaluated for cytotoxicity assays against P-388 (mouse lymphocytic leukemia), A-459 (human lung carcinoma), and HT-29 (human colon adenocarcinoma) cancer cell lines. Compounds $\mathbf{2}$ and $\mathbf{2 a}$ displayed moderate cytotoxicity against $\mathrm{P}-388$, with an $\mathrm{ED}_{50}$ of 1.81 and $3.03 \mu \mathrm{g} / \mathrm{mL}$, respectively. With the exception of the above findings, the obtained negative results showed that they were not cytotoxic against these cancer cell lines $\left(\mathrm{ED}_{50}>\right.$ $50 \mu \mathrm{g} / \mathrm{mL}$ ). The in vitro cytotoxic assays were carried out according to the procedure described previously. ${ }^{16}$

Acknowledgment. Financial support was provided by the National Science Council (NSC96-2320-B-110-003-MY3) and Ministry of Education (97C031703) of the Republic of China (Taiwan) awarded to C.-Y.D.

Supporting Information Available: ${ }^{1} \mathrm{H}$ NMR, ${ }^{13} \mathrm{C}$ NMR, COSY, NOESY, HMQC, and HMBC spectra for $\mathbf{1}$ and $\mathbf{2}$. This material is available free of charge via the Internet at http://pubs.acs.org.

OL901864D

(16) Hou, R.-S.; Duh, C.-Y.; Chiang, M. Y.; Lin, C.-N. J. Nat. Prod. 1995, 58, 1126. 